\title{
Investigation into the influence of electric field on osmosis
}

\author{
J.O. Bello ${ }^{1}$, T.M. Lawal ${ }^{2}$ and O. A. Osunkoya ${ }^{1}$ \\ ${ }^{1}$ Department of Chemical Engineering, Covenant University, Canaanland, Ota, Ogun State, \\ Nigeria \\ ${ }^{2}$ Department of Chemical Engineering, Ahmadu Bello University, Zaria, Nigeria.
}

\begin{abstract}
Investigation into influence of applied electric field on osmosis was carried out. Application of electric field on either side of the membrane was found to have effect on the osmotic flow rate. The flow rate was found to increase with increase in electric field. A $37.5 \%$ increase in amount of water transported was achieved by the application of electric field, $2000 \mathrm{~V} / \mathrm{cm}$ compared with the same system without electric field. The osmotic flow for animal bladder was considered highest among the membranes considered giving an osmotic flow rate of $4.0 \times 10^{-3} \mathrm{~cm}^{3} / \mathrm{sec}$. Using the animal bladder, water - ethanol system also gave $0.2 \mathrm{~cm}^{3}$ as the highest amount of water transported when compared with $0.150 \mathrm{~cm}^{3}, 0.13 \mathrm{~cm}^{3}$, in 50 minutes, for water-sugar and water-salt system respectively.
\end{abstract}

Keywords: Electric field, osmosis, membrane

\section{INTRODUCTION}

Application of electric field across the membrane or diaphragm was considered and the extent to which it enhances osmosis was studied. Osmosis can be defined simply as the spontaneous movement of a solute, usually water, from a place where its chemical potentials is higher to another where it is lower. The driving force for the flow being provided by the difference between the pressure of the pure water and the partial pressure of the water in solution. The osmotic phenomena has been developed in recent years and used in many chemical industries, ORMANDY919200. Osmosis has been found useful in the separation of oil-water emulsion, in the purification of clay, in the removal of water from peat, in the preparation of silica gels from sodium silicate and in electrical tanning.

The working solution considered are water, ethanol, salt and sugar using the following semi-permeable membranes, viz, Irish potatoes, yam tuber and animal bladder.

When an electrical potential is established in an aqueous solution containing charged particles, it has been noticed that charged particles will migrate according to their charge. The positive migrating to a negative electrode while the negative migrates to the positive electrode. This phenomenon is called electrophoresis. The separation of individual proteins from solution is a good example of this phenomenon. The kaolin obtained by this process of electrophoresis is of much higher purity than the usually washed kaolin.
This high purity kaolin ensures freedom from casting flows, which is caused by impurities like mica, when casting bodies. Electro-osmosis is however a process in which there is a net diffusion of charged particles in an electrical field through a semi-permeable membrane.

Literature survey: Osmosis is a mass transfer phenomena, which is by the diffusion of a substance across a differentially permeable membrane, in response to the gradient of concentration, pressure or electric potential. Osmosis was first studied in 1877 by the plant physiologist PFEFFER referred to in LIFSON (1944). His observations laid the foundation for the important theory of dilute solution of VANT HOFF recorded in THARN (1967). In the earliest recorded observation in the 18th century, an animal bladder was used as a membrane, the wall of the bladder was found to be permeable to water but not to alcohol. However, biological membranes are rarely completely semi-permeable and accurate measurements of osmotic pressure required the development of artificial membrane specially designed to be semi-permeable to the solution under investigation. It was shown that osmotic pressure is directly proportional to the concentration of solute.

The osmotic pressure is produced by the bombardment of solute molecule against the semi-permeable membrane. Part of the flow may however be by pressure induced by bulk flow rather than diffusion. A demonstration of osmosis can be done by the STAND thistle funnel method, BASFORD (1959). KATCHALSKY and CURRAN in CASEY (1962), 
expressed flow of water, solutes and electric current through a membrane in terms of their various component flows. Assuming isothermal conditions,

Water flow $=$ Hydraulic flow + Solute flow + Electroosmotic flow.

\section{EXPERIMENTAL PROCEDURE}

In this work, three types of membrane were employed, namely cellulose (yam), Irish potato and animal bladder. Water and ethanol were used as solvents while sugar solution and salt solution were used as the working solutions. A burette was clamped vertically, with the membrane fixed at the end. A working solution was put in the modified burette and the other solution in the beaker. A positive electrode was inserted in the burette while the earth electrode was inserted in the beaker.

The experiments were done in two parts viz, without electric field and with electric field for each membrane. In the case of Irish potato and yam tuber, a thickness of $0.5 \mathrm{~cm}$ was used. The circular membrane $1.8 \mathrm{~cm}$ in diameter is placed at the end of the modified burette. Flow across the membrane is from the beaker to the burette which allowed easy measurement. Copper plate $1 \mathrm{~cm}$ diameter and $2 \mathrm{~mm}$ thick served as the earth electrode while steel wire was used as the positive electrode. Initially, the wire electrode tip was placed above the surface of solution in the burette and latter placed just below the surface of the solution for a period not exceeding 20 minutes and the osmotic flow measured to determine a better position for the upper positive electrode. Runs were made with the electrode initially just above the membrane while the earth electrode stayed in the beaker. The electric field was kept constant at $2000 \mathrm{~V} / \mathrm{cm}$ while the water transported across the membrane was recorded. The results are shown in Tables 1 to 3 inclusive; representing the variation of osmotic water transported for waterethanol, water-salt, water-sugar systems for different membranes.

The variation of osmotic flowrate under varying electric field for water-ethanol, water-salt, and water-sugar is shown in Table 4, 5 and 6 respectively.

\section{DISCUSSION OF RESULTS}

Generally when animal bladder membrane was used, osmotic flow increases with time which remained constant after 45 minutes. When water was moved into ethanol, the amount of water transported doubled (100\%) from $0.1 \mathrm{~cm}^{3}$ to $0.2 \mathrm{~cm}^{3}$ in 45 minutes with electric field. This compares with only $30 \%$ increase when using water-salt solution with animal bladder membrane and $36.4 \%$ increase when using watersugar solution for the animal bladder, upon the application of electric field. The yam membrane, showed a $40 \%$ increase in water transported for the water-ethanol when field was applied.

For water-salt solution the amount (using no field) reduced to $0.08 \mathrm{~cm}^{3}$, a $20 \%$ decrease, even though the amount collected under electric field was $0.10 \mathrm{~cm}^{3}$ which is a $20 \%$ increase, this was actually smaller when compared to the amount obtained using the previous membrane.

There was also an increase from $0.10 \mathrm{~cm}^{3}$ to $0.12 \mathrm{~cm}^{3}$ of amount of water transported using yam. When the test was conducted without electric field was compared to the one done under the applied field. Using watersugar solution. For this membrane water-ethanol solution gave the highest amount of water transported by osmosis, which was $0.14 \mathrm{~cm}^{3}$, for osmosis under electric field. In water-salt solution the lowest amount of water $\left(0.07 \mathrm{~cm}^{3}\right)$ was transported.

The results obtained using Irish potato membrane, showed that: for water-ethanol osmosis $0.11 \mathrm{~cm}^{3}$ water was transported within a space time of 50minutes when no electric field was applied. But there was a $27 \%$ increase in the amount of water transported when the osmosis was observed under applied electric field.

For water-salt solution the amount collected now falls to $0.07 \mathrm{~cm}^{3}$ and $0.09 \mathrm{~cm}^{3}$ respectively in the two experiments. These were the least amount transported using this membrane. The volume of water transported by osmosis is $0.08 \mathrm{~cm}^{3}$ when using water-sugar solution which is higher than the amount obtained in the former case. When electric field was applied a 37.5\% increase in amount of water transported was achieved, which amounted to the highest using this membrane.

On the average, water transported with the application of electric field is $0.13 \mathrm{~cm}^{3}$ compared with $0.0956 \mathrm{~cm}^{3}$ under no electric field. This represents a $37 \%$ increase on the volume of water delivered.

For the three sets of solvents, graphs of applied voltage against osmotic flowrates were plotted. From these graphs for Electric field, E, between zero to $2000 \mathrm{~V} / \mathrm{cm}$ and osmotic flowrates ranging from 0 to 400 $\times 10^{-3} \mathrm{~cm}^{3} / \mathrm{min}$, it was observed that osmotic flowrates increase with increase in applied voltage, especially for animal bladder and yam membranes. The effect was more pronounced in the case of animal bladder but least on potato membrane. Water-ethanol solution have the highest osmotic flowrate than the other two solutions, water-salt solution has the least, thence the 
reason could be due to the presence of ionised $\mathrm{Na}^{+}$ and $\mathrm{Cl}^{-}$ions present in the aqueous solution.

Therefore from the calculated percentage increase in osmotic flowrate (37.45\%), upon the application of electric field it could be concluded without prejudice that osmosis was influenced by the application of electric field across the membrane. Within the range of voltage applied and osmotic flow rates computed.
This result compared favourably with a similar one of YVETTE (1957), it is also to an extent in accordance with the results obtained by KOBATAKE (1967) in which potassium chloride and lithium chloride aqueous solution were tested by using oxidised collodion membranes and volume flows were measured under the conditions in which either pressure difference or electric potential differences was applied.

Table 1 Osmotic water transported across different membrane with and without electric field using waterlethanol solution.

\begin{tabular}{|c|c|c|c|c|c|c|}
\hline \multirow{5}{*}{$\begin{array}{l}\text { Time } \\
\text { (Mins) }\end{array}$} & \multicolumn{2}{|c|}{ Animal Bladder Membrane } & \multicolumn{2}{|c|}{ Yam Membrane } & \multicolumn{2}{|c|}{ Irish Potato Membrane } \\
\hline & W/ TO No figld & W TO & WTO & \multirow{4}{*}{$\begin{array}{l}\text { W.T.O with } \\
\text { Field } 200 \mathrm{~V} / \mathrm{cm} \\
\left(\mathrm{Cm}^{3}\right)\end{array}$} & WT & \multirow{4}{*}{$\begin{array}{l}\text { W.T.O. with } \\
\text { Field } 200 \mathrm{~V} / \mathrm{cm} \\
\left(\mathrm{Cm}^{3}\right)\end{array}$} \\
\hline & W.T.O No field & W.T.O & W.T.O & & W.T.O & \\
\hline & $\left(\mathrm{Cm}^{3}\right)$ & with & No Field $\left(\mathrm{Cm}^{3}\right)$ & & No Field $\left(\mathrm{Cm}^{3}\right)$ & \\
\hline & & $2000 \mathrm{~V} / \mathrm{cm}$ & & & & \\
\hline 5 & 0.01 & 0.05 & 0.03 & 0.03 & 0.03 & 0.05 \\
\hline 10 & 0.03 & 0.07 & 0.05 & 0.05 & 0.04 & 0.06 \\
\hline 15 & 0.04 & 0.08 & 0.06 & 0.07 & 0.05 & 0.08 \\
\hline 20 & 0.05 & 0.1 & 0.07 & 0.08 & 0.06 & 0.09 \\
\hline 25 & 0.06 & 0.11 & 0.08 & 0.09 & 0.07 & 0.1 \\
\hline 30 & 0.07 & 0.13 & 0.08 & 0.09 & 0.08 & 0.11 \\
\hline 35 & 0.08 & 0.14 & 0.09 & 0.11 & 0.09 & 0.12 \\
\hline 40 & 0.09 & 0.17 & 0.09 & 0.12 & 0.1 & 0.13 \\
\hline 45 & 0.1 & 0.19 & 0.1 & 0.13 & 0.11 & 0.14 \\
\hline 50 & 0.11 & 0.2 & 0.1 & 0.14 & 0.11 & 0.14 \\
\hline
\end{tabular}

WTO* Water Transported across by Osmosis.

Table 2 Osmotic water transported across different membrane with and without electric field using water/salt solution.

\begin{tabular}{|c|c|c|c|c|c|c|}
\hline \multirow{4}{*}{$\frac{\text { Time }}{\text { (Mins) }}$} & \multicolumn{2}{|c|}{ Animal Bladder Membrane } & \multicolumn{2}{|c|}{ Yam Membrane } & \multicolumn{2}{|c|}{ Irish Potato Membrane } \\
\hline & W.T.O & W.T.O & W.T.O & \multirow{3}{*}{$\begin{array}{l}\text { W.T.O with } \\
\text { Field } 200 \\
\text { VIcm }\left(\mathrm{Cm}^{3}\right)\end{array}$} & \multirow{3}{*}{$\begin{array}{l}\text { W.T.O } \\
\begin{array}{l}\text { No Field } \\
\left(\mathrm{Cm}^{3}\right)\end{array} \\
\end{array}$} & \multirow{3}{*}{$\begin{array}{l}\text { W.T.O. with Field } \\
200 \mathrm{~V} / \mathrm{cm}\left(\mathrm{Cm}^{3}\right)\end{array}$} \\
\hline & No field & with & $\begin{array}{l}\text { No Field } \\
\left(\mathrm{Cm}^{3}\right)\end{array}$ & & & \\
\hline & $\left(\mathrm{Cm}^{3}\right)$ & $2000 \mathrm{~V} / \mathrm{cm}$ & & & & \\
\hline 5 & 0.03 & 0.05 & 0.01 & 0.01 & 0.01 & 0.01 \\
\hline 10 & 0.04 & 0.06 & 0.02 & 0.02 & 0.02 & 0.03 \\
\hline 15 & 0.05 & 0.08 & 0.03 & 0.04 & 0.02 & 0.03 \\
\hline 20 & 0.06 & 0.1 & 0.04 & 0.05 & 0.03 & 0.04 \\
\hline 25 & 0.07 & 0.11 & 0.04 & 0.06 & 0.03 & 0.05 \\
\hline 30 & 0.07 & 0.11 & 0.05 & 0.07 & 0.04 & 0.06 \\
\hline 35 & 0.08 & 0.12 & 0.06 & 0.08 & 0.05 & 0.07 \\
\hline 40 & 0.08 & 0.12 & 0.06 & 0.09 & 0.06 & 0.07 \\
\hline 45 & 0.09 & 0.13 & 0.07 & 0.1 & 0.07 & 0.08 \\
\hline 50 & 0.1 & 0.13 & 0.08 & 0.1 & 0.07 & 0.09 \\
\hline
\end{tabular}

WTO is the Water Transported across by Osmosis. 
Am. J. Sci. Ind. Res., 2010, 1(2): 213-219

Table 3 Osmotic water transported across different membrane with and without electric field using watersugar solution.

\begin{tabular}{|c|c|c|c|c|c|c|}
\hline \multirow{3}{*}{$\begin{array}{l}\text { Time } \\
\text { (Mins) }\end{array}$} & \multicolumn{2}{|c|}{ Animal Bladder Membrane } & \multicolumn{2}{|c|}{ Yam Membrane } & \multicolumn{2}{|c|}{ Irish Potato Membrane } \\
\hline & \multirow{2}{*}{$\begin{array}{l}\text { W.T.O } \\
\text { No field }\end{array}$} & \multirow{2}{*}{$\begin{array}{l}\text { W.T.O } \\
\text { with }\end{array}$} & \multirow{2}{*}{$\begin{array}{l}\text { W.T.O } \\
\text { No Field } \\
\left(\mathrm{Cm}^{3}\right)\end{array}$} & \multirow{2}{*}{$\begin{array}{l}\text { W.T.O with } \\
\text { Field } 200 \\
\text { V/cm }\left(\mathrm{Cm}^{3}\right)\end{array}$} & \multirow{2}{*}{$\begin{array}{l}\text { W.T.O } \\
\text { No Field }\left(\mathrm{Cm}^{3}\right)\end{array}$} & \multirow{2}{*}{$\begin{array}{l}\text { W.T.O. with Field } \\
200 \mathrm{~V} / \mathrm{cm}\left(\mathrm{Cm}^{3}\right)\end{array}$} \\
\hline & & & & & & \\
\hline 5 & 0.02 & 0.03 & 0.02 & 0.02 & 0.01 & 0.02 \\
\hline 10 & 0.03 & 0.04 & 0.03 & 0.04 & 0.02 & 0.03 \\
\hline 15 & 0.04 & 0.05 & 0.04 & 0.05 & 0.03 & 0.04 \\
\hline 20 & 0.05 & 0.06 & 0.05 & 0.06 & 0.04 & 0.05 \\
\hline 25 & 0.06 & 0.07 & 0.06 & 0.07 & 0.05 & 0.06 \\
\hline 30 & 0.07 & 0.08 & 0.07 & 0.08 & 0.06 & 0.07 \\
\hline 35 & 0.08 & 0.1 & 0.08 & 0.09 & 0.07 & 0.08 \\
\hline 40 & 0.09 & 0.12 & 0.09 & 0.1 & 0.07 & 0.09 \\
\hline 45 & 0.11 & 0.15 & 0.09 & 0.1 & 0.08 & 0.1 \\
\hline 50 & 0.11 & 0.15 & 0.1 & 0.12 & 0.08 & 0.11 \\
\hline
\end{tabular}

WTO is the Water Transported across by Osmosis.

Table 4 Osmotic flowrates of Water-Ethanol under Applied Electric Field.

\begin{tabular}{|c|c|c|c|}
\hline $\begin{array}{l}\text { Electric } \\
\text { field } \\
\text { (V/cm) }\end{array}$ & \multicolumn{3}{|c|}{$\begin{array}{l}\text { Osmotic flow rates of water- } \\
\text { ethanol solution }\left(\mathrm{Cm}^{3} \text { /min) } \times \mathbf{1 0}^{-3}\right.\end{array}$} \\
\hline & $\begin{array}{l}\text { Animal } \\
\text { Bladder }\end{array}$ & Yam & Irish Potato \\
\hline 0 & 2.2 & 2 & 2.2 \\
\hline 500 & 2.4 & 2.2 & 2.4 \\
\hline 1000 & 3 & 2.4 & 2.6 \\
\hline 1500 & 3.4 & 2.6 & 2.7 \\
\hline 2000 & 4 & 2.8 & 2.8 \\
\hline
\end{tabular}

Table 5 Osmotic flowrates of Water-Salt solution under varying Applied Electric Field.

\begin{tabular}{|c|c|c|c|}
\hline $\begin{array}{l}\text { Electric } \\
\text { field } \\
\text { (V/cm) }\end{array}$ & \multicolumn{3}{|l|}{$\begin{array}{l}\text { Osmotic flow rates of water-ethanol } \\
\text { solution }\left(\mathrm{Cm}^{3} \text { /min) } \times \mathbf{~ 1 0}^{-3}\right.\end{array}$} \\
\hline & $\begin{array}{c}\text { Animal } \\
\text { Bladder }\end{array}$ & Yam & Irish Potato \\
\hline 0 & 2 & 1.6 & 1.4 \\
\hline 500 & 2.2 & 1.7 & 1.5 \\
\hline 1000 & 2.4 & 1.8 & 1.6 \\
\hline 1500 & 2.5 & 1.9 & 1.7 \\
\hline 2000 & 2.6 & 2 & 1.8 \\
\hline
\end{tabular}

Table 6 Osmotic flowrates of Water-Sugar solution under varied Electric Field.

\begin{tabular}{|c|c|c|c|}
\hline $\begin{array}{l}\text { Electric } \\
\text { field } \\
\text { (VIcm) }\end{array}$ & \multicolumn{3}{|c|}{$\begin{array}{l}\text { Osmotic flow rates of water-ethanol } \\
\text { solution }\left(\mathrm{Cm}^{3} \text { Imin) } \times \mathbf{1 0}^{-3}\right.\end{array}$} \\
\hline & $\begin{array}{c}\text { Animal } \\
\text { Bladder }\end{array}$ & Yam & $\begin{array}{c}\text { Irish } \\
\text { Potato }\end{array}$ \\
\hline 0 & 2.2 & 2 & 1.6 \\
\hline 500 & 2.4 & 2.1 & 1.7 \\
\hline 1000 & 2.6 & 2.2 & 1.9 \\
\hline 1500 & 2.9 & 2.3 & 2 \\
\hline 2000 & 3 & 2.4 & 2.2 \\
\hline & & & \\
\hline
\end{tabular}


Am. J. Sci. Ind. Res., 2010, 1(2): 213-219

H.T.

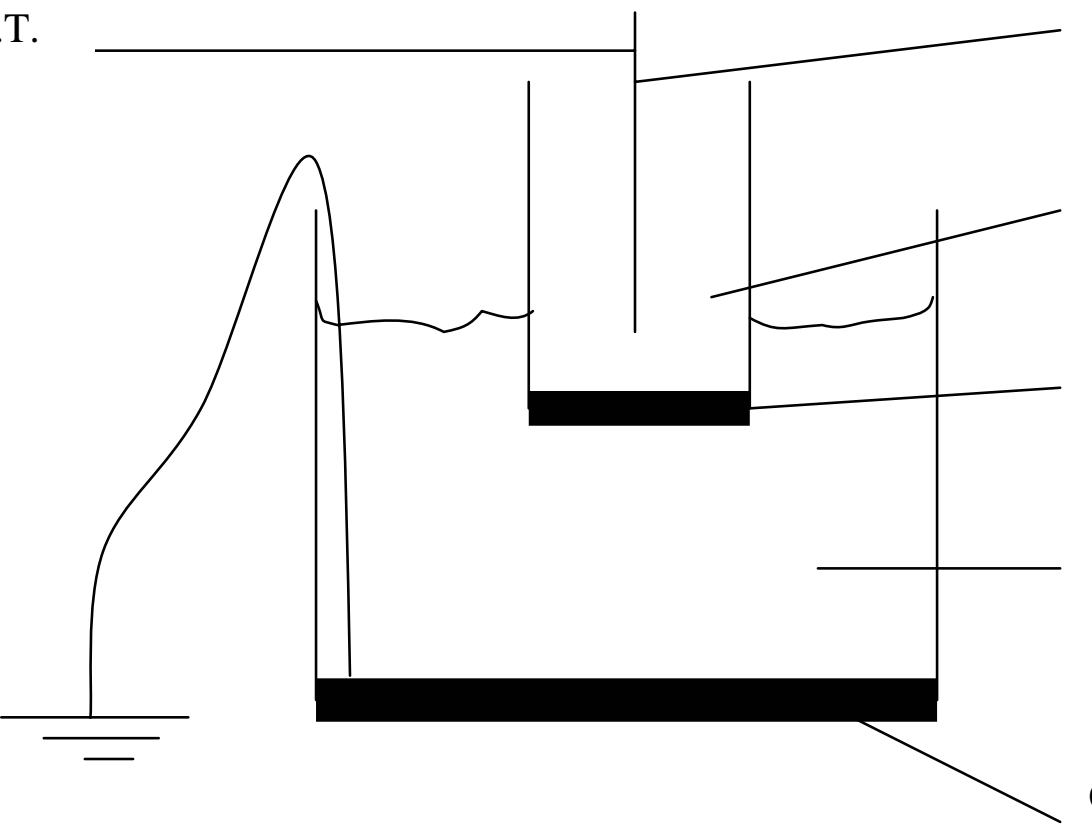

Steel Wire

Solvent

Membrane

Solution

Fig 1. Experimental Set-up

\section{Copper Sheet electrode}

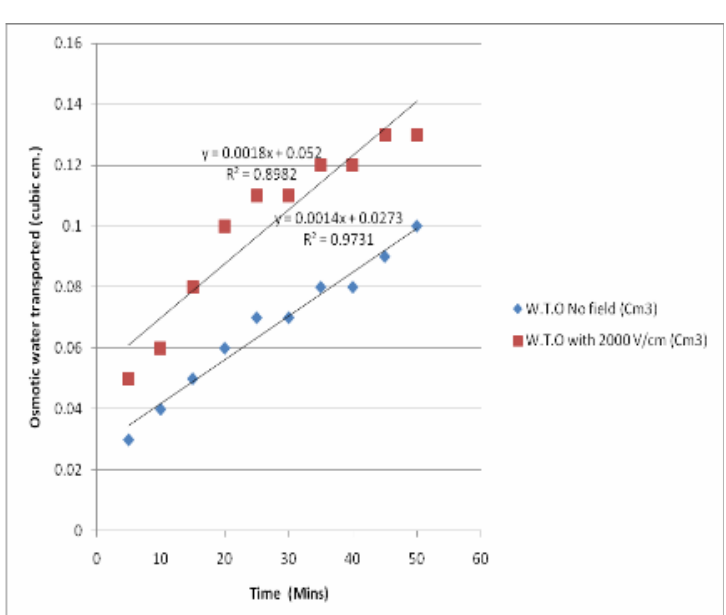

Fig 3 Variation of Osmotic water transported with time or without $2000 \mathrm{~V} / \mathrm{cm}$ electric field for water-salt system (animal bladder membrane).

Fig 2 Variation of Osmotic water transported with time or without $2000 \mathrm{~V} / \mathrm{cm}$ electric field for water-ethanol system (animal bladder membrane). 
Am. J. Sci. Ind. Res., 2010, 1(2): 213-219

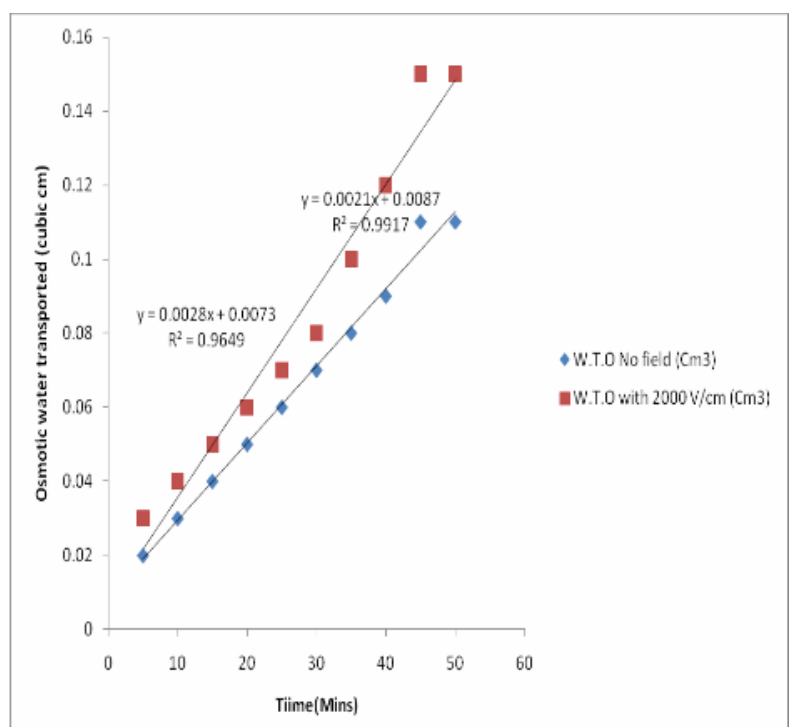

Fig 4 Variation of Osmotic water transported with time or without $2000 \mathrm{~V} / \mathrm{cm}$ electric field for water-Sugar system (animal bladder membrane).

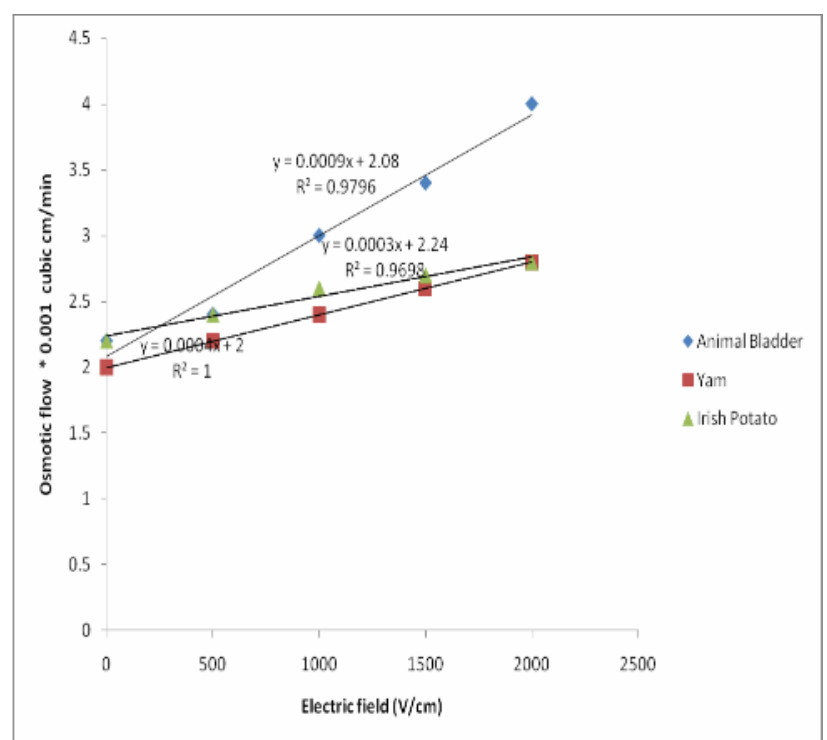

Fig 5 Variation of Electric field with osmotic flow for water ethanol solution

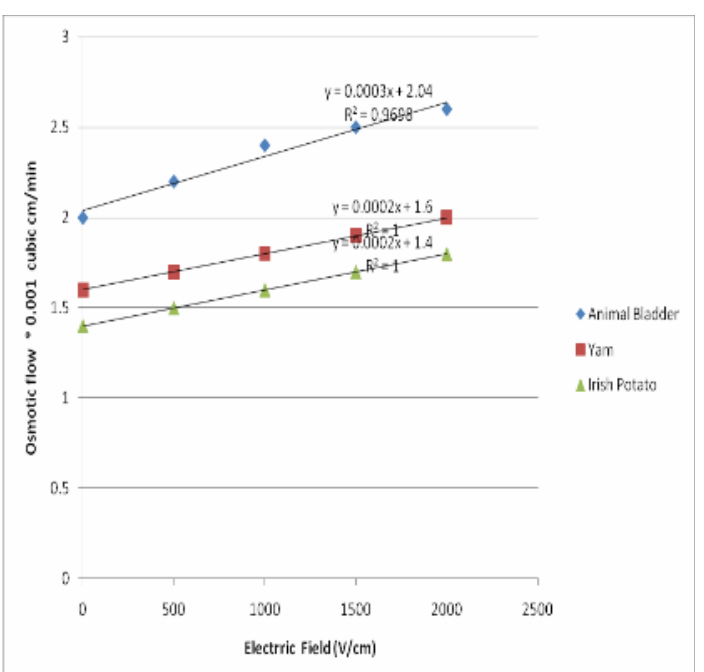

Fig 6 Variation of Electric field with osmotic flow for water -salt solution

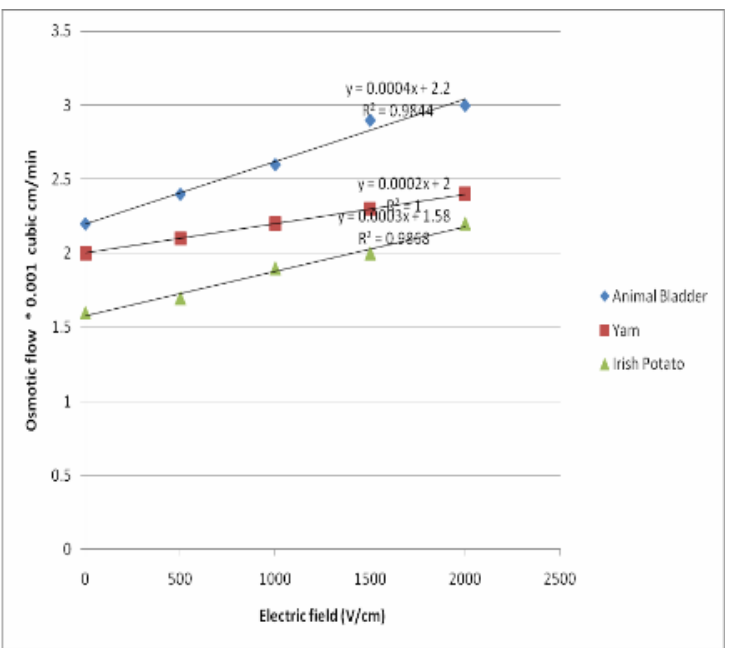

Fig 7 Variation of Electric field with osmotic flow for water-sugar solution

\section{CONCLUSIONS}

From the investigations carried out and the results obtained the following conclusion could be drawn:

1. Osmotic flow increase with time. Typically it increased from $0.01 \mathrm{~cm}^{3}$ to $0.11 \mathrm{~cm}^{3}$ from 5 minutes to 50 minutes. More water passes across the membrane due to water molecules concentration gradient.

2. Higher amount of water was transported through the membrane when animal bladder was used compared with other membranes. Osmotic flow of $0.20 \mathrm{~cm}^{3}$ in 50 minutes was recorded for animal membrane against $0.07 \mathrm{~cm}^{3}$. With this result the animal bladder has better porosity thus 
Am. J. Sci. Ind. Res., 2010, 1(2): 213-219

more permeable to the passage of water molecules; moreover it is favoured by its thin thickness.

3. The calculated percentage increase in amount of water transported upon the application of electric field is $37.45 \%$. More water was transported on the application of externally applied electric field across the membrane. It can therefore be suggested that electric field enhances osmotic flow. This confirms the reports of YVETTE (1957) and KOBATAKE (1967).

4. It can also be concluded that osmotic flow depends on

i. the type of materials used for the membrane,

ii. the pore area.

iii. the diameter of the membrane used, and iv. the strength of the applied field.

\section{REFERENCES}

Basford, F.R.(1959) School Sc. Rev. 39, 94-95.

Casey, C.J.(1962) Biophysics Concept and Mechanism, pp36-42, Reinhold Corporation, Inc New York (1962).

Eugene, A.(1979) Biophysical Science, pp 30 -35, Prentice Hall Inc and Eaglewood, New Jersey.

James, S.(1979) "Studies in Biology (Plant and Water)", 14 2nd Edtn, Edward Arnold Ltd, London .

Kobatake, Y. and Yuasa., M (1967).J. Phy. Chem. pp 1752 1757, U.S. .

Lifson, N. and Visscher, N.B.(1944) "Osmosis in living systems", Medical Physics, edited by Glassier O. 1 .

Ormandy, W.R.(1920) Chem. Age. (London) 3 , 374 .

Tharn J.F.(1967), Principle of Osmotic Phenomena.

Yvette. L. and SERGE DE M.(1957) Comprehensive Review, 246, 2048-2051, United States of America . 